\title{
Penerapan Algoritma Naive Bayes untuk Analisis Sentimen Review Data Twitter BMKG Nasional
}

\author{
Dedi Darwis ${ }^{1, *}$, Nery Siskawati ${ }^{1}, Z^{\text {Zaenal Abidin }}{ }^{1}$ \\ ${ }^{1}$ Fakultas Teknik dan Ilmu Komputer, Universitas Teknokrat Indonesia, Bandar Lampung, Indonesia \\ ${ }^{*}$ darwisdedi@teknokrat.ac.id
}

\begin{abstract}
Abstrak- Pertumbuhan Twitter terus meningkat setiap waktu, sehingga hal tersebut dimanfaatkan para pengguna Twitter untuk menyampaikan informasi berupa kritik maupun saran kepada pelayanan yang diberikan BMKG Nasional dengan lebih mudah. Metode yang digunakan dalam penelitian ini adalah klasifikasi data adalah Naïve Bayes Classifier (NBC). Sistem yang dikembangkan dengan menggunakan data internal yang diambil dari internet/Twitter untuk proses penentuan kalimat termasuk opini positif, netral atau negatif. Penentuan tersebut digolongkan sebagai proses pengklasifikasian. Serta menggunakan Application Python 3.74. Hasil Penelitian ini masuk kedalam fined grained sentiment analysis yaitu analisis pada suatu kalimat komentar. Data tersebut akan diproses menggunakan text mining, kemudian dilanjutkan dengan mengklasifikasikan Tweet ke dalam tiga kelas, yaitu positif, negatif, dan netral. Klasifikasi ini menggunakan algoritma naive bayes. Klasifikasi dapat memberikan kemudahan bagi pengguna untuk melihat opini positif, negatif, dan netral. Hasil uji akurasi pada metode naive bayes untuk klasifikasi yaitu $69.97 \%$
\end{abstract}

Kata Kunci: Analisis Sentimen, Naive Bayes, Python 3.74, Twitter.

Abstract - Twitter growth continues to increase every time, so it is used by Twitter users to convey information in the form of criticism and suggestions to the services provided by the National BMKG more easily. The method used in this study is the classification of data is the Naïve Bayes Classifier (NBC). The system was developed using internal data taken from the internet / Twitter for the process of determining sentences including positive, neutral or negative opinions. The determination is classified as a classification process. And using Python 3.74 application. The results of this study are included in the fined grained sentiment analysis, which is an analysis in a comment sentence. The data will be processed using text mining, then proceed with classifying Tweets into three classes, namely positive, negative, and neutral. This classification uses the Naive Bayes algorithm. Classification can make it easy for users to see positive, negative and neutral opinions. The results of the accuracy test on the Naive Bayes method for classification are $69.97 \%$.

Keywords: Sentiment Analysis, Naive Bayes, Python 3.74, Twitter.

\section{PENDAHULUAN}

\subsection{Latar Belakang Masalah}

Perkembangan teknologi internet saat ini membawa dampak perubahan pada beberapa sektor kehidupan manusia, seperti hanya pada bidang pendidikan, perdagangan, pemerintahan hingga komunikasi social. Di era sekarang ini pertumbuhan internet dan media sosial telah berkembang pesat sehingga menyediakan berbagai informasi opini dari orang lain. Sebuah survey yang dilakukan oleh Asosiasi Pengusaha Jasa Internet (APJII) pada tahun 2014 menunjukkan bahwa jumlah pengguna internet di Indonesia mengalami kenaikan dalam beberapa tahun terakhir. Pada tahun 2005, tercatat sebanyak 16 juta orang pengguna internet di Indonesia dan angka ini bertambah menjadi 20 juta orang pengguna internet pada tahun 2006. Penelitian ini juga memberikan hasil bahwa saat ini penggunaan internet paling banyak adalah akses ke situs media sosial (87,4\% dari total responden), salah satu media social pada zaman sekarang yaitu Twitter [1].

Media sosial Twitter adalah salah satu sebagau media penghubung yang diminati oleh seluruh masyarakat di dunia [2]. Hal ini dapat dilihat dari jumlah peningkatan pengguna Twitter yang tercatat di seluruh dunia salah satunya indonesia. Pada saat ini Twitter memiliki jumlah pengguna aktif sebesar 313 juta per bulan pada tahun 2016 [3]. Pengguna Twitter akan memberikan kabar terbaru atau komentar tentang hal yang sedang menjadi topik utama di dunia. Hal yang sedang menjadi topik utama dan banyak dan sering dikomentari oleh pengguna akan menimbulkan suatu masalah atau trending topik di media sosial terutama Twitter.

Pertumbuhan Twitter terus meningkat setiap waktu [4], sehingga hal tersebut dimanfaatkan para pengguna Twitter untuk menyampaikan informasi berupa komentar kritik maupun saran kepada pelayanan yang diberikan BMKG Nasional dapat dilakukan dengan lebih mudah. Semakin banyak pendapat atau keluhan dari beberapa masyarakat dalam membentuk opini masyarakat, dan dapat dijadikan masukan terhadap suatu penilaian pelayanan yang diberikan BMKG Nasional. Pada pelayanan yang diberikan oleh salah satu petugas BMKG Nasional yang kurang baik maka akan menimbulkan banyak opini masyarakat tentang pelayanan BMKG Nasional. Analisis sentimen dapat membantu untuk memperoleh gambaran umum presepsi masyarakat dengan 
cara mengelompokkan jenis opini menjadi kategori positif, negatif, atau netral terhadap pelayanan pada BMKG Nasional.

Algoritma Naive Bayes adalah merupakan salah satu algoritma klasifikasi yang banyak digunakan pada Data Mining ataupun Text Mining [5]. Algoritma Naive Bayes berdasarkan teorema Bayes bahwa semua kegiatan memberikan sebuah kontribusi yang sama penting atau saling bebas pada pemilihan kelas tertentu. Salah satu metode klasifikasi untuk menentukan gambaran persepsi masyarakat di dalam Text Mining adalah metode Nä̈ve Bayes yang sering disebut dengan Naive Bayes Classifier [6], [7].

Penelitian yang dilakukan adalah tentang sentimen analisis untuk mengklasifikasikan Tweet Review BMKG Nasional. Penelitian ini termasuk kedalam sebuah penelitian yang bernama fined grained sentiment analysis yaitu analisis pada suatu kalimat komentar. Data dari Twitter tersebut akan dapat diproses menggunakan text mining, kemudian dilanjutkan dengan mengklasifikasikan Tweet ke dalam tiga kelas, yaitu positif, negatif, dan netral. Klasifikasi dapat memberikan kemudahan bagi semua pengguna untuk melihat kritik dan saran [8], [9]. Tujuan penelitian ini adalah untuk melakukan pencarian komentar negatif, postif, dan netral dengan review data Twitter BMKG Nasional menggunakan algoritma naive bayes, lalu melakukan perhitungan data negatif, postif, dan netral menggunakan algoritma naïve bayes, serta dapat menghasilkan klasifikasi berdasarkan nilai yang didapat dengan algoritma naive bayes. Penelitian yang dilakukan difokuskan kepada kritik dan saran dalam pelayanan BMKG Nasional yang ada di akun resmi Twitter dengan menggunakan data pada tahun 2018 dan 2019. Proses pengambilan data dan klasifikasi sentimen analisis menggunakan bahasa pemrograman Python 3.74.

\subsection{Landasan Teori}

a. Analisis Sentiman

Analisis Sentimen adalah salah satu cabang sebuah penelitian text mining, yang berkaitan dengan bidang yang lebih luas seperti pengolahan data kegiatan tertentu [3].

\section{b. Text Mining}

Text Mining merupakan tahapan proses dari analisis dalam data yang berupa teks dimana sumber data didapatkan dari suatu dokumen seperti kalimat data kata, Konsep text mining biasanya digunakan dalam klasifikasi dokumen tekstual dimana dokumen-dokumen tersebut akan diklasifikasikan sesuai dengan topik dokumen tersebut [9].

c. Naive Bayes

Salah satu tugas Data Mining adalah klasifikasi data, yaitu memetakan (mengklasifikasikan) data ke dalam satu kelas atau beberapa kelas yaang sudah didefinisikan sebelumnya. Salah satu metoda dalam klasifikasi data adalah Naïve Bayes yaitu salah satu metode machine learning yang memanfaatkan perhitungan probabilitas dan statistik yang dikemukakan oleh ilmuwan Inggris Thomas Bayes, cara kerja Naive Bayes yaitu memprediksi probabilitas di masa depan berdasarkan pengalaman di masa sebelumnya [7]. Dasar dari Naïve Bayes yang dipakai dalam pemrograman adalah rumus Bayes seperti pada persamaan (1)

$\mathrm{P}(\mathrm{A} \mid \mathrm{B})=(\mathrm{P}(\mathrm{B} \mid \mathrm{A}) * \mathrm{P}(\mathrm{A})) / \mathrm{P}(\mathrm{B})$

Keterangan :

Peluang kejadian A sebagai B ditentukan dari peluang B saat A, peluang A, dan peluang B.

Pada pengaplikasiannya nanti rumus pada persamaan (1) berubah menjadi persamaan (2).

$\mathrm{P}(\mathrm{Ci} \mid \mathrm{D})=(\mathrm{P}(\mathrm{D} \mid \mathrm{Ci}) * \mathrm{P}(\mathrm{Ci})) / \mathrm{P}(\mathrm{D})$

Naïve Bayes atau bisa disebut sebagai Multinomial Naïve Bayes merupakan model penyederhanaan dari Metoda Bayes yang cocok dalam pengklasifikasian teks atau dokumen.

Pada persamaan (3) merupakan persamaan model penyederhanaan dari Metoda Bayes.

$\mathrm{VMAP}=\arg \max \mathrm{P}(\mathrm{Vj} \mid \mathrm{a} 1, \mathrm{a} 2, \ldots \ldots . . \mathrm{an})$

Berdasarkan persamaan (3), maka persamaan (1) dapat ditulis seperti yang terdapat pada persamaan (4)

$$
\mathrm{V}_{\mathrm{MAP}}=\operatorname{agr} \max (\mathrm{Vj} \mathrm{eV}) \frac{P(a 1, a 2 \ldots \ldots a n|P(V j)|}{P(a 1, a 2 \ldots . . a n)}
$$




\section{METODE PENELITIAN}

\subsection{Kerangka Penelitian}

Kerangka penelitian dibuat untuk membuat pola pikir penelitian menjadi lebih realistik. Pada penelitian yang dilakukan, gambaran tentang kerangka penelitian yang dibuat disajikan pada Gambar 1.

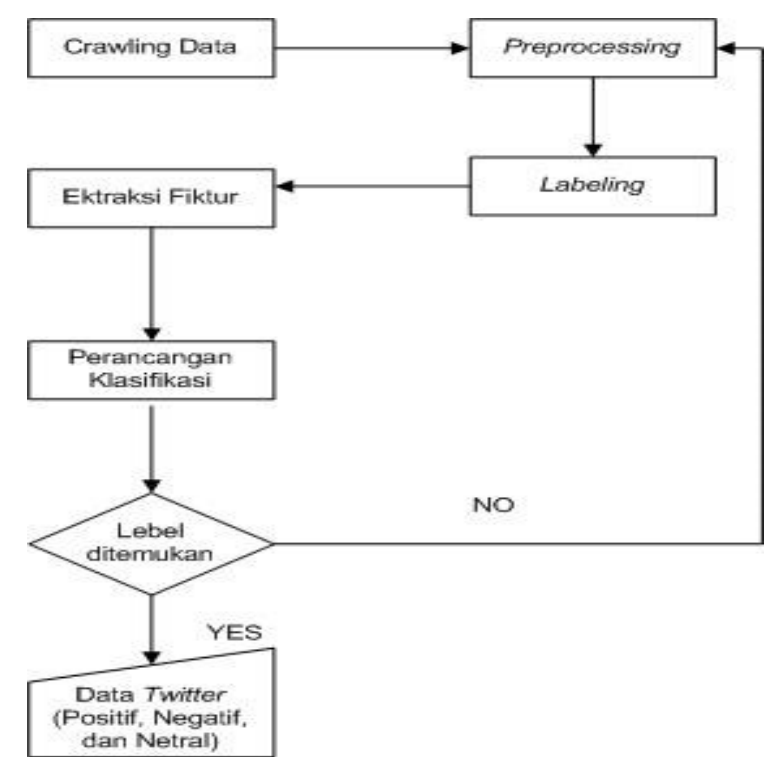

Gambar 1. Kerangka Penelitian

Penjelasan pada Gambar 1.

a. Crawling Data, yaitu data Twitter berisi opini masyarkat yang mengandung unsur komentar postif, netral, dan negatif pada BMKG dengan data tahun 2018-2019 melalui aplikasi Twitter. Pada proses ini dimulai dari melakukan kunjungan Twitter BMKG kemudian menuju ke folder clone dan mulai melakukan penyaringan data dengan Python.

b. Pelabelan sentimen Tweet menjadi netral, positif atau negatif

c. Preprocessing, dilakukan untuk menghasilkan data bersih. Preprocessing meliputi: casefolding, filtering,tokenisasi, slang replacement dan stopwordremoval.

d. Ekstraksi Fitur, meliputi: Unigram, Negation, $T F$ dan $T F-I D F$.

e. Perancangan klasifikasi, dilakukan untuk mengelompokkan Tweet berdasarkan kelas yang ditentukan.

f. Lebel ditemukan, digunakan untuk menemukan klasifikasi data baru menggunakan Nä̈ve Bayes.

\subsection{Tahapan Penelitian}

Tahapan penelitian dalam pengambilan data sentimen analisis berupa Tweet negatif, positif, dan netral pada Twitter BMKG, dapat dilihat pada Gambar 2. 


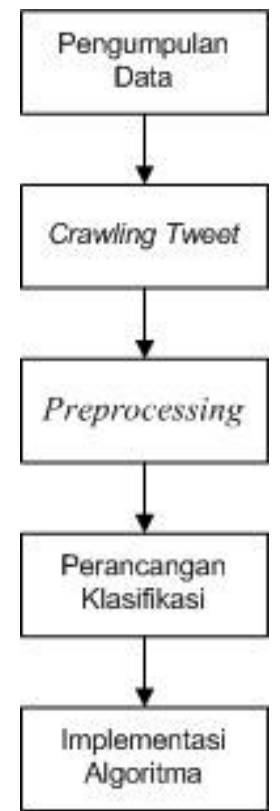

Gambar 2. Tahapan Penelitian

\subsection{Cara Kerja Sentimen Analisis}

Proses klasifikasi menggunakan data pada tahun 2018-2019 pada Twitter BMKG. Tweet dibagi ke dalam tiga kelas kata, yaitu positif, netral dan negatif. Setiap dokumen yang diklasifikasi akan di kategorikan ke dalam kelas yang paling dominan, berikut ini adalah tahapan yang dilakukan :

a. Crawler Twitter Akun BMKG

Crawler merupakan sebuah alat untuk mengindeks dan mengunduh konten dari internet, lalu disimpan ke dalam database mesin pencari [10]. Berikut ini adalah hasil crawl Twitter akun BMKG salah satu dari komentar yang ada pada akun BMKG, sebagai contoh yaitu :

ari10prasetyo @ BMKG @Awas aja kalau alat kayak gini masih ada :)

b. Case Folding

Case folding merupakan proses untuk mengubah kalimat atau menjadi huruf kecil [11]. Berikut ini adalah contoh hasil Case Folding akun BMKG salah satu dari komentar yang ada pada akun BMKG yaitu :

ari10prasetyo@bmkg@awas aja kalau alat kayak gini masih ada :)

c. Cleansing

Data cleansing adalah kegiatan menganalisa kualitas data dengan cara memodifikasi, mengubah, atau menghapus data-data yang dianggap tidak perlu, tidak lengkap, data tidak akurat, atau memiliki format data atau file yang salah dalam basis data guna menghasilkan data berkualitas tinggi. Data cleansing juga biasa disebut data cleaning atau data scrubbing [12]. Berikut ini adalah contoh Cleansing akun dengan mencantumkan komentar yang dilakukan tanpa adanya nama pengomentar.

awas aja kalau alat kayak gini masih ada :)

d. Stopword Removal

Stopword removal disebut juga filtering, adalah tahap pemilihan kata-kata penting dari hasil token, yaitu kata-kata apa saja yang akan digunakan untuk mewakili dokumen [13]. Berikut ini adalah stopword removal yang dilakukan yaitu proses penyatuan dan pergantian emot yang dilakukan oleh pengomentar, dapat dilihat dibawah ini :

: Alat kayak gini masih ada, tapi emot senang

e. Tokenisasi

Tokenisasi adalah proses memisahkan deretan kata di dalam kalimat, paragraf atau halaman menjadi tokenatau potongan kata tunggal atau termmed word yang berdiri sendiri [14]. Berikut ini adalah contoh proses tekonesiasi yaitu penyaringan kata yang dilakukan oleh pengomentar. 
Alat, kayak, gini, masih ada

\subsection{Metode Pengumpulan Data}

Pada penelitian ini digunakan data sekunder yang diambil dari akun Twitter resmi BMKG Nasional. Data yang diambil akan dijadikan sebagai data training untuk membuat kamus opini. Pembuatan kamus data opini tersebut dengan mengumpulkan data opini melalui media data online. Kamus data opini yang dikumpulkan diklasifikasi menjadi kamus opini negatif dan positif. Untuk melakukan klarifikasi peneliti mengunakan bantuan secara online maupun offline untuk melakukan klarifikasi agar data kamus sesuai dan meminimalkan subjektifitas.

Aplikasi yang dikembangkan menggunakan data internal yang diambil dari internet/Twitter untuk proses penentuan kalimat termasuk opini positif, netral atau negatif. Penentuan tersebut digolongkan sebagai proses pengklasifikasian. Pengklasifikasian padasuatu dokumen termasuk kelas positif, kelas netralatau kelas negatif. Didalam pengumpulan data ini juga menggunakan study literature dengan data skunder yang didapat dari internet/Twitter.

\subsection{Proses Twitter Crawling}

Proses crawling pada Twitter dilakukan dengan memanfaatkan fasilitas yang ada pada bahasa pemrograman Python 3.74 yang telah disediakan. Dengan terlebih dahulu melakukan pengambilan data aplikasi pada Twitter Developer. Analisis sentiment pada penelitian ini dibatasi pada BMKG, dan menghasilkan penyimpanan data dalam format CSV. Gambar 2 merupakan potongan source code untuk mengambil data pada Twitter.

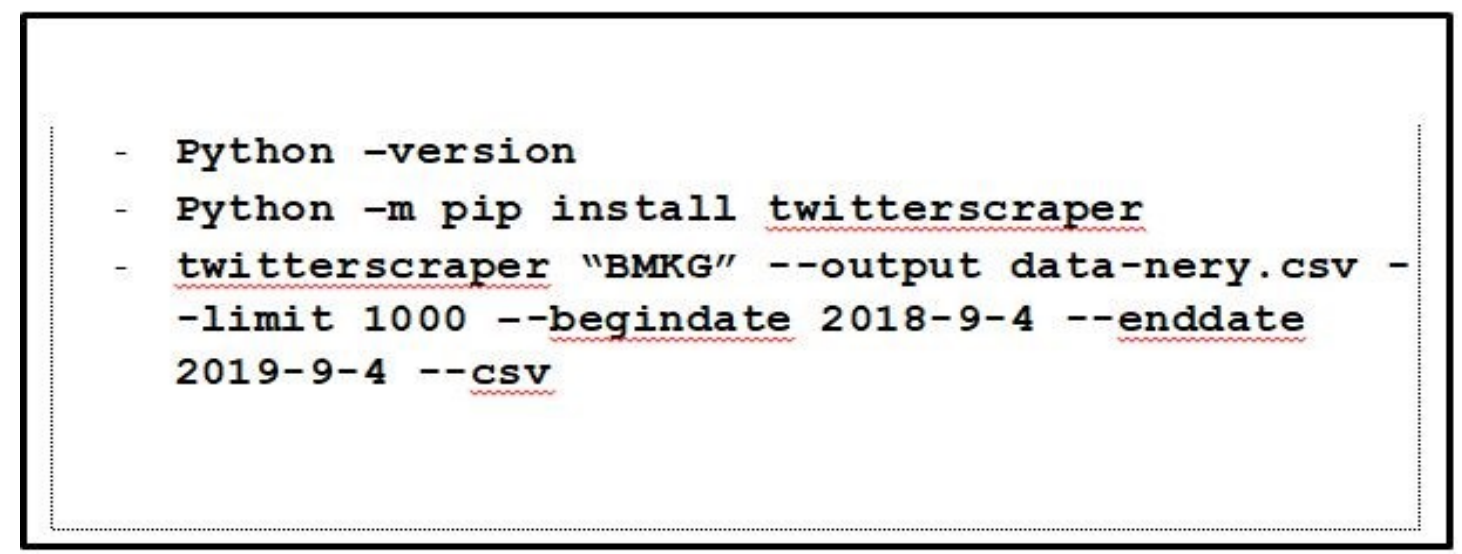

Gambar 3. Potongan Source Code Crawling Data Twitter

Dari data hasil crawling selanjutnya disimpan pada file dengan format CSV. Gambar 4 menunjukkan contoh data yang akan disimpan untuk proses pembentukan model. 


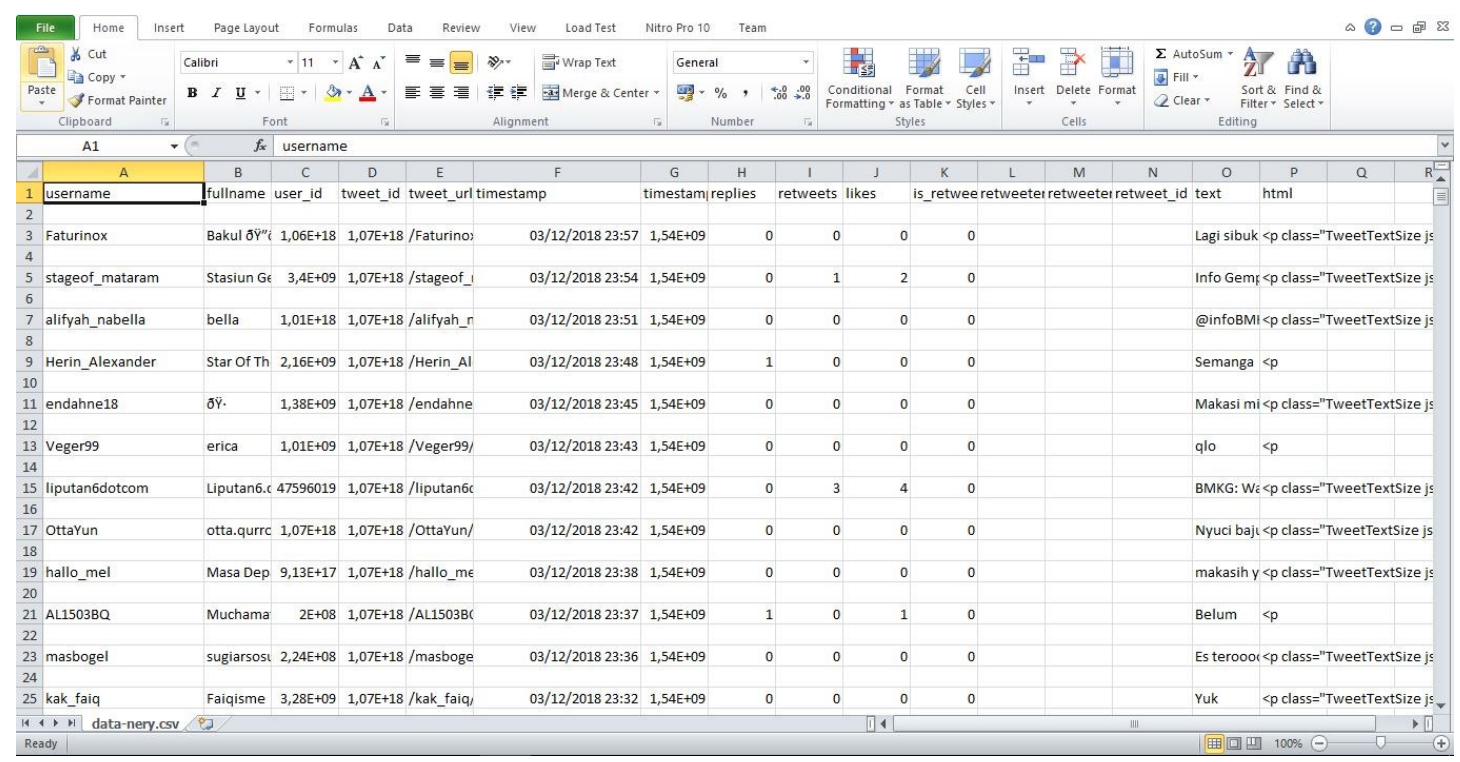

Gambar 4. Hasil Crawling Data Twitter dalam Format CSV

\subsection{Skenario Pengujian}

Pada skenario pengujian ini jumlah data yang digunakan adalah 1179 dataTweet. Data dibagi menjadi dua bagian yaitu data training dan data testing dengan perbandingan 70:825 dimana data yang digunakan tersebut sudah diberi label. Oleh algoritma Naive Bayes Classifier(NBC), data training digunakan untuk membentuk tabel probabilitas, dan data testing digunakan untuk menguji tabel probabilitas yang telah terbentuk atau dapat diasumsikan bahwa data training adalah data yang digunakan sebagai acuan untuk membangun model klasifikasi, sedangkan data testing adalah data yang digunakan untuk menguji performa dari model klasifikasi tersebut.

Pada skenario pengujian ini data training sudah dipersiapkan sebelumnya dan disimpan ke dalam dataset. Hasil data training (pembelajaran) yang didapat akan diuji dengan data baru yang masih belum diketahui classtype kategorinya. Pada penelitian ini terdapat proses preprocessing. Adapun tahapan ini adalah Normalisasi fitur, tokenizing, stop-words, dan stemming. Proses ini bertujuan untuk mendapatkan data training yang sesuai harapan si analis. Disini penulis melakukan variasi pada tahap preprocessing dengan menghilangkan salah satu tahapan preprocessing yaitu tahap Normalisasi fitur. Pada tahapan ini penulis ingin mengetahui tingkat akurasi ketika salah satu tahapan dihilangkan apakah akan berpengaruh pada hasil akurasi atau tidak. Tabel 1 merupakan pembagian data training dan data testing dalam proses pengujian.

Tabel 1. Pembagian Data Training dan Data Testing

\begin{tabular}{cccc}
\hline No & Class & Data Training & Data Testing \\
\hline 1 & Positif & 931 & 354 \\
2 & Negatif & 70 & 354 \\
3 & Netral & 178 & 354 \\
& Total & 1179 & 1179 \\
\hline
\end{tabular}

\section{HASIL DAN PEMBAHASAN}

\subsection{Menghitung Probabilitas Kata}

Menghitung probabilitas kata dilakukan untuk bertujuan mendapatkan term dengan nilai yang lebih penting dan dianggap relevan untuk dijadikan kata kunci. Proses pembobotan menggunakan algoritma Naive Bayes Classifier dalam proses perhitungan persamaan dapat dilihat pada Tabel 2 . 
Tabel 2. Contoh Kemunculan Term Frekuensi

\begin{tabular}{cccc}
\hline \multirow{2}{*}{ Kata } & \multicolumn{3}{c}{ Frekuensi kemunculan kata $\left(\mathrm{W}_{\mathrm{k}}\right)$} \\
\cline { 2 - 4 } & $\begin{array}{c}354 \text { Tweet } \\
\text { Positif }\end{array}$ & $\begin{array}{c}\text { 354Tweet } \\
\text { Negatif }\end{array}$ & $\begin{array}{c}354 \text { Tweet } \\
\text { Netral }\end{array}$ \\
\hline Pagi & 189 & 7 & - \\
Cuaca & 7 & 3 & 5 \\
Baik & 13 & 1 & 6 \\
Oke & 5 & 3 & - \\
Hoak & 1 & 1 & - \\
Jangan & 6 & 1 & 1 \\
Salah & 3 & - & - \\
Bantu & 2 & - & 1 \\
Mungkin & 2 & 5 & - \\
Tumben & - & 2 & - \\
\hline
\end{tabular}

Selanjutnya mencari probabilitas kata pagi, cuaca, baik, oke, hoak, jangan, salah, bantu, mungkin, tumben: Diketahui :

$\begin{array}{ll}\mathrm{n} \text { Tweet } \text { Positif } & : 354 \\ \mathrm{n} \text { Tweet } \text { Negatif } & : 354 \\ \mathrm{n} \text { Tweet } \text { Netral } & : 354\end{array}$

a. Kata Pagi

$$
\begin{aligned}
& \mathrm{P}(\text { Pagi } \mid \text { Positif })= \\
& \text { 189+1 } \\
& 354+825=0,16 \\
& \mathrm{P}(\text { Pagi } \mid \text { Negatif })= \\
& 7+1 \\
& 54+825 \\
& \mathrm{P}(\text { Pagi } \mid \text { Netral })= \\
& 0+1 \\
& 354+825
\end{aligned}
$$

b. Kata Cuaca

$$
\begin{aligned}
& \mathrm{P}(\text { Cuaca } \mid \text { Positif })=\quad \frac{7+1}{354+825}=0,006 \\
& \mathrm{P}(\text { Cuaca } \mid \text { Negatif })= \\
& \frac{3+1}{354+825}=0,003 \\
& \mathrm{P}(\text { Cuaca } \mid \text { Netral })= \\
& \frac{5+1}{354+825}=0,005
\end{aligned}
$$

c. Kata Baik

$$
\begin{aligned}
& \mathrm{P}(\text { baik } \mid \text { Positif })= \\
& 13+1 \\
& \begin{array}{ll}
\mathrm{P}(\text { baik } \mid \text { Negatif })= & 1+1 \\
(\text { baik } \mid \text { Netral })= & \begin{array}{c}
354+825 \\
6+1
\end{array}
\end{array} \\
& 354+825
\end{aligned}
$$


d. Kata oke

$\mathrm{P}($ Oke $\mid$ Positif $)=\quad \frac{5+1}{354+825}=0,005$
$\mathrm{P}($ Oke $\mid$ Negatif $)=$
$\frac{3+1}{354+825}=0,003$
$\mathrm{P}($ Oke $\mid$ Netral $)=$
$\frac{0+1}{354+825}=0,0008$

e. Kata Hoak

\begin{tabular}{|c|c|c|c|}
\hline \multirow{2}{*}{$\mathrm{P}($ Hoak $\mid$ Positif $)=$} & $1+1$ & \multirow{2}{*}{$=$} & \multirow{2}{*}{0,0016} \\
\hline & $354+825$ & & \\
\hline \multirow{2}{*}{$\mathrm{P}($ Hoak $\mid$ Negatif $)=$} & $1+1$ & \multirow{2}{*}{$=$} & \multirow{2}{*}{0,0016} \\
\hline & $354+825$ & & \\
\hline \multirow{3}{*}{$\mathrm{P}($ Hoak $\mid$ Netral $)=$} & $0+1$ & \multirow{3}{*}{$=$} & \multirow{3}{*}{0,0008} \\
\hline & 254025 & & \\
\hline & $354+825$ & & \\
\hline
\end{tabular}

f. Kata Jangan

$$
\begin{aligned}
& \mathrm{P}(\text { jangan } \mid \text { Positif })=\frac{6+1}{354+825}=0,0059 \\
& \begin{array}{l}
\mathrm{P}(\text { jangan } \mid \text { Negatif })= \\
\frac{6+1}{354+825}=0,0059 \\
\mathrm{P}(\text { jangan } \mid \text { Netral })=
\end{array}
\end{aligned}
$$

g. Kata Salah

$$
\begin{aligned}
& \mathrm{P}(\text { Salah } \mid \text { Positif })= \\
& \frac{0+1}{354+825}=0,003 \\
& \mathrm{P}(\text { Salah } \mid \text { Negatif })= \\
& \frac{0+1}{354+825}=0,0008 \\
& \mathrm{P}(\text { Salah } \mid \text { Netral })=
\end{aligned}
$$

h. Kata Bantu

$$
\begin{aligned}
& \mathrm{P}(\text { Bantu } \mid \text { Positif })= \\
& \frac{2+1}{354+825}=0,0025 \\
& \mathrm{P}(\text { Bantu } \mid \text { Negatif })= \\
& 0+1=0,0008
\end{aligned}
$$




$\mathrm{P}($ Bantu $\mid$ Netral $)=\frac{1+1}{354+825}=0,0016$

i. Kata Mungkin

\begin{tabular}{|c|c|c|c|}
\hline \multirow{2}{*}{$\mathrm{P}($ Mungkin $\mid$ Positif $)=$} & $2+1$ & \multirow{2}{*}{$=$} & \multirow{2}{*}{0,0025} \\
\hline & $354+825$ & & \\
\hline \multirow{2}{*}{$\mathrm{P}($ Mungkin $\mid$ Negatif $)=$} & $5+1$ & \multirow{2}{*}{$=$} & \multirow{2}{*}{0,005} \\
\hline & $354+825$ & & \\
\hline \multirow[b]{2}{*}{$\mathrm{P}($ Mungkin $\mid$ Netral $)=$} & $0+1$ & \multirow[b]{2}{*}{$=$} & \multirow[b]{2}{*}{0,0008} \\
\hline & & & \\
\hline
\end{tabular}

j. Kata Tumben

$$
\begin{aligned}
& \mathrm{P}(\text { Tumben } \mid \text { Positif })=\frac{0+1}{354+825}=0,0008 \\
& \mathrm{P}(\text { Tumben } \mid \text { Negatif })=\frac{2+1}{354+825}=0,0025 \\
& \mathrm{P}(\text { Tumben } \mid \text { Netral })=\quad \frac{0+1}{354+825}=0,0008
\end{aligned}
$$

Setelah mendapatkan hasil dari probabilitas kata, kemudian akan menghitung probabilitas dari dokumen (Tweet) sampel atau contoh. Diasumsikan $\mathrm{P}\left(\mathrm{V}_{\mathrm{j}}\right)$ (probabilitas kategori dokumen) sama dengan docs $j$ (jumlah dokumen setiap kategori) dibagi dengan $\mid$ contoh $\mid$ (jumlah dokumen yang digunakan sebagai data training dari seluruh kategori). Diperoleh persamaan (5).

$P\left(v_{j}\right)=\frac{\mid \text { doc }_{j} \mid}{\mid \text { Contoh } \mid}$

Perhitungan probabilitas Tweetdimana terdapat 1179Tweetyang terbagi 354 Tweet kelas positif, 354Tweet kelas negatif dan 354 Tweet kelas netral :

$$
\begin{array}{ll}
\mathrm{P}(\text { Positif })= & \frac{354}{1179}=0,3 \\
\mathrm{P}(\text { Negatif })= & =0,3 \\
\mathrm{P}(\text { Netral })= & \frac{354}{1179}=0,3
\end{array}
$$

Data kata dari Tweet nilai probabilitas dapat dilihat pada Tabel 3. 
Tabel 3. Daftar Uji Kata

\begin{tabular}{ccccc}
\hline No & Kata & Prob positif V1 & Prob Negatif V2 & Prob Netral V3 \\
& & & & \\
\hline 1 & Pagi & 0,16 & 0.006 & 0,0008 \\
2 & Cuaca & 0,006 & 0,003 & 0,005 \\
3 & Baik & 0,0011 & 0,0016 & 0,005 \\
4 & Oke & 0,005 & 0,003 & 0,0008 \\
5 & Hoak & 0,0016 & 0,0016 & 0,0008 \\
6 & Jangan & 0,0059 & 0,0059 & 0,0016 \\
7 & Salah & 0,003 & 0,0008 & 0,0008 \\
8 & Bantu & 0,0025 & 0,0008 & 0,0016 \\
9 & Mungkin & 0,0025 & 0,005 & 0,0008 \\
10 & Tumben & 0,0008 & 0,0025 & 0,0008 \\
\hline
\end{tabular}

Untuk mendapatkan nilai probabilitas nilai tertinggi langkah pertama yakni menghitung $\left(P\left(W_{k 1} \mid V_{j}\right) P\left(V_{j}\right)\right.$ ). $P\left(V_{j}\right)$ didapat probabilitas dokumen:

\begin{tabular}{|c|c|c|}
\hline $\begin{array}{cl}\text { Kata } & \text { (Pagi|Positif) } \\
& \text { (Pagi|Negatif) } \\
& \text { (Pagi|Netral) }\end{array}$ & $\begin{array}{l}: 0,16 * 0,3 \\
: 0,006 * 0,3 \\
: 0,0008 * 0,3\end{array}$ & $\begin{array}{l}=0,048 \\
=0,0018 \\
=0,00024\end{array}$ \\
\hline $\begin{array}{l}\text { (Cuaca|Positif) } \\
\text { (Cuaca|Negatif) } \\
\text { (Cuaca|Netral) }\end{array}$ & $\begin{array}{l}: 0,006 * 0,3 \\
: 0,003 * 0,3 \\
: 0,005 * 0,3\end{array}$ & $\begin{array}{l}=0,0018 \\
=0,0009 \\
=0,0015\end{array}$ \\
\hline $\begin{array}{l}\text { (Baik|Positif) } \\
\text { (Baik|Negatif) } \\
\text { (Baik|Netral) }\end{array}$ & $\begin{array}{l}: 0,011 * 0,3 \\
: 0,0016 * 0,3 \\
: 0,0045 * 0,3\end{array}$ & $\begin{array}{l}=0,0033 \\
=0,00048 \\
=0,00135\end{array}$ \\
\hline $\begin{array}{l}\text { (Ok|Positif) } \\
\text { (Ok|Negatif) } \\
\text { (Ok|Netral) }\end{array}$ & $\begin{array}{l}: 0,005 * 0,3 \\
: 0,003 * 0,3 \\
: 0,0008 * 0,3\end{array}$ & $\begin{array}{l}=0,0015 \\
=0,0009 \\
=0,00024\end{array}$ \\
\hline $\begin{array}{l}\text { (Hoak|Positif) } \\
\text { (Hoak|Negatif) } \\
\text { (Hoak|Netral) }\end{array}$ & $\begin{array}{l}: 0,0016 * 0,3 \\
: 0,0016 * 0,3 \\
: 0,0008 * 0,3\end{array}$ & $\begin{array}{l}=0,00048 \\
=0,00048 \\
=0,00024\end{array}$ \\
\hline $\begin{array}{l}\text { (Jangan|Positif) } \\
\text { (Jangan|Negatif) } \\
\text { (Jangan|Netral) }\end{array}$ & $\begin{array}{l}: 0,0059 * 0,3 \\
: 0,0059 * 0,3 \\
: 0,0016 * 0,3\end{array}$ & $\begin{array}{l}=0,0017 \\
=0,0017 \\
=0,0048\end{array}$ \\
\hline $\begin{array}{l}\text { (Salah|Positif) } \\
\text { (Salah|Negatif) } \\
\text { (Salah|Netral) }\end{array}$ & $\begin{array}{l}: 0,003 * 0,3 \\
: 0,0008 * 0,3 \\
: 0,0008 * 0,3\end{array}$ & $\begin{array}{l}=0,0009 \\
=0,00024 \\
=0,00024\end{array}$ \\
\hline $\begin{array}{l}\text { (Bantu|Positif) } \\
\text { (Bantu|Negatif) } \\
\text { (Bantu|Netral) }\end{array}$ & $\begin{array}{l}: 0,0025 * 0,3 \\
: 0,0008 * 0,3 \\
: 0,0016 * 0,3\end{array}$ & $\begin{array}{l}=0,00075 \\
=0,00024 \\
=0,00048\end{array}$ \\
\hline $\begin{array}{l}\text { (Mungkin|Positif) } \\
\text { (Mungkin|Negatif) } \\
\text { (Mungkin|Netral) }\end{array}$ & $\begin{array}{l}: 0,0025 * 0,3 \\
: 0,005 * 0,3 \\
: 0,0008 * 0,3\end{array}$ & $\begin{array}{l}=0,00075 \\
=0,0015 \\
=0,00024\end{array}$ \\
\hline $\begin{array}{l}\text { (Tumben|Positif) } \\
\text { (Tumben|Negatif) } \\
\text { (Tumben|Netral) }\end{array}$ & $\begin{array}{l}: 0,0008 * 0,3 \\
: 0,0025 * 0,3 \\
: 0,0008 * 0,3\end{array}$ & $\begin{array}{l}=0,00024 \\
=0,00075 \\
=0,00024\end{array}$ \\
\hline
\end{tabular}

Setelah itu menghitung nilai probabilitas tertinggi dari masing-masing kategori. 
Probabilitas Positif Tertinggi $=0,048 * 0,0018 * 0,0033 * 0,0015 * 0,00048 * 0,0017 * 0,0009 * 0,00075 *$ $0,00075 * 0.00024=4.24019059 \mathrm{e}-29$

Probabilitas Negatif Tertinggi $=0,0018 * 0,0009 * 0,00048 * 0,000 * 0,00048 * 0,00017 * 0,00024 * 0,00024 *$ $0,0015 * 0,00075=3.70052997 \mathrm{e}-33$

Probabilitas Netral Tertinggi $=0,00024 * 0,0015 * 0,00135 * 0,0002 * 0,00024 * 0,00048 * 0,00024 * 0,00048$ * $0,00024 * 0.00024=8.91610045 \mathrm{e}-35$

Tabel 4. Nilai Probabilitas

\begin{tabular}{ccc}
\hline $\begin{array}{c}\text { Probabilitas Positif } \\
\text { Tertinggi }\end{array}$ & $\begin{array}{c}\text { Probabilitas Negatif } \\
\text { Tertinggi }\end{array}$ & $\begin{array}{c}\text { Probabilitas Netral } \\
\text { Tertinggi }\end{array}$ \\
\hline $4.24019059 \mathrm{e}-29$ & $3.70052997 \mathrm{e}-33$ & $8.91610045 \mathrm{e}-35$ \\
\hline
\end{tabular}

Dari perhitungan algoritma naive bayesy ang dilakukan, kemudian dicari perbandingan nilai probabilitas tertinggi dari masing-masing Tweet sehingga Tweet yang sudah di testing dapat di kategorikan kedalam dokumenTweet opini yang sesuai dengan isi teksnya. Pada tabel 4 dapat dilihat hasil dari keseluruhan proses perhitungan probabilitas tertinggi dengan naive bayes. Pada tabel tersebut probabilitas positif memiliki nilai tertinggi.Sehingga dapat dipastikan Tweet yang dipilih merupakan dokumen Tweet positif.

\subsection{Pembahasan}

\subsubsection{Hasil Pembagian Data}

Berikut adalah rekapan hasil pembangian data positif, netral, dan negatif dapat dilihat pada Tabel 5, 6, 7 dan 8 .

Tabel 5. Kasus Data Training Positif

\begin{tabular}{|c|c|c|}
\hline Tweet & Kalimat & Label \\
\hline Tweet 1 & Dengarkan update informasi & Positif \\
\hline Tweet 2 & baik, tunggu. terimakasih banyak & Positif \\
\hline Tweet3 & silakan kami sudah respon pesan terimakasih & Positif \\
\hline Tweet4 & Peringatan dini cuaca wilayah Kalimantan Tengah & Positif \\
\hline Tweet 5 & Selamat Pagi, mohon informasi yang akurat, terima kasih. & Positif \\
\hline Tweet6 & $\begin{array}{l}\text { Cuaca di Jakarta hari ini (23/6) diperkirakan cerah dan } \\
\text { berawan sepanjang hari. }\end{array}$ & Positif \\
\hline Tweet7 & $\begin{array}{l}\text { Bahkan BMKG gak bikin peringatan dini buat Kepulauan } \\
\text { Bangka Belitung }\end{array}$ & Positif \\
\hline Tweet8 & Utara Jawa dong min & Positif \\
\hline Tweet9 & Prediksi BMKG Jogja bisa mencapai suhu $8 \hat{\mathrm{A}}^{\circ} \mathrm{c}$ & Positif \\
\hline Tweet 10 & $\begin{array}{l}\text { Aku selalu bilang sama oppung, ada terpasang info bmkg } \\
\text { pung di hpku jd tau nnti kalo ada peringatan,tenang aja } \\
\text { oppung. Bbrp bulan lalu, tiba tiba laut surut jauh. } \\
\text { Seingatku kami ngungsi akhirnya sampe jam } 5\end{array}$ & Positif \\
\hline
\end{tabular}


Tabel 6. Kasus Data Training Negatif

\begin{tabular}{|c|c|c|}
\hline Tweet & Kalimat & Label \\
\hline Tweet 1 & Awas aja, kalo alat ini masih ada & Negatif \\
\hline Tweet 2 & Sini aju naik, sini aku naikin gajinya & Negatif \\
\hline Tweet 3 & Setiap nebak pasti ditolak & Negatif \\
\hline Tweet 4 & $\begin{array}{l}\text { \#Gempa Mag:3.2, 16-Nov-18 02:00:36 WIB, Lok:2.99 } \\
\text { LS, } 119.50 \text { BT (Pusat gempa berada di darat } 21 \mathrm{~km} \\
\text { Tenggara Mamasa), Kedlmn:10 Km Dirasakan (MMI) III } \\
\text { Mamasa \#BMKG... }\end{array}$ & Negatif \\
\hline Tweet5 & Dirasakan di Lombok Barat juga & Negatif \\
\hline Tweet 6 & $\begin{array}{l}\text { RT BpbdTrenggalek "Prakiraan cuaca Kabupaten } \\
\text { Trenggalek }\end{array}$ & Negatif \\
\hline Tweet 7 & $\begin{array}{l}\text { Yaudah sih, lagian ini juga BNPB bukan BMKG yg } \\
\text { ngasih Info. }\end{array}$ & Negatif \\
\hline Tweet 8 & $\begin{array}{l}\text { Sumpah gue lagi tidur semalem kaya ada yg nyenggol } \\
\text { jadi parno eh tau tau gempa }\end{array}$ & Negatif \\
\hline Tweet9 & Emang due kepala kok sok2an sambat ngelu? & Negatif \\
\hline Tweet 10 & Aku ga keroso i min & Negatif \\
\hline
\end{tabular}

Tabel 7. Kasus Data Training Netral

\begin{tabular}{|c|c|c|}
\hline Tweet & Kalimat & Label \\
\hline Tweet 1 & Bmkg itu bakso malang karapitan group & Netral \\
\hline Tweet2 & Nggak ada yang dibuat rebahan & Netral \\
\hline Tweet3 & Kenceng apanya Grid? Akhir bulan aku pulang. & Netral \\
\hline Tweet 4 & $\begin{array}{l}\text { Aku itu punya aplikasi @infoBMKG tiap ada gempa } \\
\text { selalu ada info, sekecil apapun }\end{array}$ & Netral \\
\hline Tweet 5 & Gempi mksd e? & Netral \\
\hline Tweet6 & Mosok ee, pengalaman ledome wkw & Netral \\
\hline Tweet 7 & Nyuci baju selesai dan hujan pun turun & Netral \\
\hline Tweet8 & Belum ada pak & Netral \\
\hline Tweet9 & Yo lek mbak e turu gk kerasa & Netral \\
\hline Tweet 10 & $\begin{array}{l}\text { Gk keroso min, turuku anteng paling, tangi } 2 \text { wes adan } \\
\text { subuh. }\end{array}$ & Netral \\
\hline Tweet4 & $\begin{array}{l}\text { Aku itu punya aplikasi @infoBMKG tiap ada gempa } \\
\text { selalu ada info, sekecil apapun }\end{array}$ & Netral \\
\hline Tweet5 & Gempi mksd e? & Netral \\
\hline Tweet6 & Mosok ee, pengalaman ledome wkw & Netral \\
\hline Tweet7 & Nyuci baju selesai dan hujan pun turun & Netral \\
\hline
\end{tabular}




\begin{tabular}{|c|c|c|}
\hline Tweet & Kalimat & Label \\
\hline Tweet 8 & Belum ada pak & Netral \\
\hline Tweet 9 & Yo lek mbak e turu gk kerasa & Netral \\
\hline Tweet 10 & $\begin{array}{l}\text { Gk keroso min, turuku anteng paling, tangi } 2 \text { wes adan } \\
\text { subuh. }\end{array}$ & Netral \\
\hline Tweet 4 & $\begin{array}{l}\text { Aku itu punya aplikasi @infoBMKG tiap ada gempa } \\
\text { selalu ada info, sekecil apapun }\end{array}$ & Netral \\
\hline Tweet 5 & Gempi mksd e? & Netral \\
\hline Tweet6 & Mosok ee, pengalaman ledome wkw & Netral \\
\hline Tweet 7 & Nyuci baju selesai dan hujan pun turun & Netral \\
\hline Tweet 8 & Belum ada pak & Netral \\
\hline Tweet9 & Yo lek mbak e turu gk kerasa & Netral \\
\hline Tweet 10 & $\begin{array}{l}\text { Gk keroso min, turuku anteng paling, tangi } 2 \text { wes adan } \\
\text { subuh. }\end{array}$ & Netral \\
\hline
\end{tabular}

Tabel 8. Pembagian Data Training

\begin{tabular}{ccc}
\hline No & Class & Data Training \\
\hline 1 & Positif & 931 \\
2 & Negatif & 70 \\
3 & Netral & 178 \\
& Total & 1179 \\
\hline
\end{tabular}

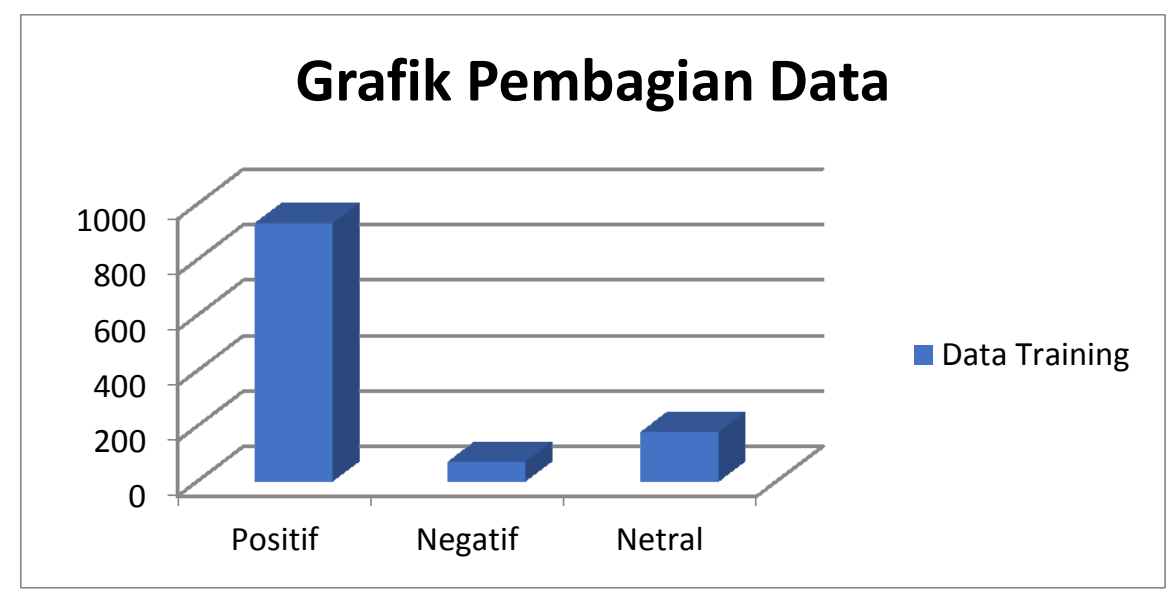

Gambar 5. Grafik Pembagian Data

\subsubsection{Akurasi Data}

Akurasi adalah penghitungan dari perbandingan antara jumlah data dokumen yang relevan dan jumlah keseluruhan dokumen dalam database [15]. Menghitung akurasi dapat menggunakan persamaan 6. 
Akurasi $=\frac{\text { Jumlah Dokumen Relevan }}{\text { Jumlah Keseluruhan Dokumen }}$

Akurasi $=\frac{825}{1179}$

Akurasi $=69,97 \%$

Berdasarkan hasil pembahasan, dari proses dan tahapan preprocessing yang dilakukan Tweet yang mengungkapkan sebuah eksprsi positif dan membuat Tweet tersebut terbaca negatif karena kesalahan. Hal ini dikarenakan masih ada yang terbaca negatif meskipun Tweet yang disertai menununjukan Tweet positif. Tabel 9 menunjukkan contoh kesalahan Tweet yang didapat.

Tabel 9. Contoh Kesalahan Tweet

\begin{tabular}{|c|c|c|c|}
\hline Tweet & Positif & Negatif & Netral \\
\hline Bantu pantau hilal jodoh saya min @infoBMKG (positif) & & & $\sqrt{ }$ \\
\hline Wahwahh (netral) & & $\sqrt{ }$ & \\
\hline Jalan ma aku aja (negatif) & & & $\sqrt{ }$ \\
\hline Tidur min, mau temanin saya nonton bola? (negatif) & $\sqrt{ }$ & & \\
\hline min ini bener atau hoax y? (positif) & & $\sqrt{ }$ & \\
\hline Aku disemagati oleh diriku sendiri (positif) & & $\sqrt{ }$ & \\
\hline $\begin{array}{l}\text { Notif dari tadi gak ada notif WA atau line isi nya notif } \\
\text { (positif) }\end{array}$ & & $\sqrt{ }$ & \\
\hline $\begin{array}{l}\text { Bahkan yang selalu serius pun butuh waktu rehat sejenak } \\
\text { untuk menghela nafas, dan tersenyum (positif) }\end{array}$ & & $\sqrt{ }$ & \\
\hline
\end{tabular}

Dengan menghilangkan salah satu tahapan preprocessing seperti yang penulis lakukan yaitu dengan menghilangkan tahapan Normalisasi fitur sangat berpengaruh dengan nilai akurasi yang dihasilkan karena dapat mengurangi hasil akurasi pada klasifikasi Tweet.

\section{KESIMPULAN}

Berdasarkan hasil penelitian dan pembahasan yang dilakukan, maka terdapat beberapa kesimpulan yaitu :

1. Proses ekstrakasi data dari Twitter BMKG Nasional menggunakan Bahasa pemrograman Python 3.74 dengan tahapan Preprocessing yang meliputi casefolding, filtering, tokenisasi, slang replacement dan stopword removal.

2. Sentimen analisis yang dilakukan adalah membuat tiga kelas yaitu postif, negatif dan netral menggunakan algoritma klasifikasi Naive Bayes.

3. Tingkat akurasi berdasarkan pengujian yang dilakukan adalah $68,97 \%$.

\section{REFERENCES}

[1] Apji, “Asosiasi Pengusaha Jasa Internet Indonesia,” Jakarta, 2014.

[2] D. Darwis, E. S. Pratiwi, and A. F. O. Pasaribu, "DATA TWITTER KOMISI PEMBERANTASAN KORUPSI REPUBLIK INDONESIA,” J. Ilm. Edutic, vol. 7, no. 1, pp. 1-11, 2020.

[3] A. Samad, H. Basari, B. Hussin, I. G. Pramudya, and J. Zeniarja, "Opinion Mining of Movie Review using Hybrid Method of Support Vector Machine and Particle Swarm Optimization Opinion Mining of Movie Review using Hybrid Method of Support Vector Machine and Particle Swarm Optimization," Procedia Eng., vol. 53, no. December, pp. 453-462, 2013, doi: 10.1016/j.proeng.2013.02.059.

[4] M. A. Assuja and Saniati, “Analisis Sentimen Tweet Menggunakan,” J. Tek., vol. 10, no. 2, pp. 23-28, 2016.

[5] A. P. Wijaya, H. A. Santoso, J. T. Informatika, U. Dian, and N. Semarang, "Naive Bayes Classification pada Klasifikasi Dokumen Untuk Identifikasi Konten E-Government,” J. Appl. Intell. Syst., vol. 1, no. 1, pp. 48-55, 2016.

[6] A. R. Isnain, A. Sihabuddin, and Y. Suyanto, "Bidirectional Long Short Term Memory Method and Word2vec Extraction Approach for Hate Speech Detection," IJCCS (Indonesian J. Comput. Cybern. Syst., vol. 14, no. 2, 2020. 
[7] A. Amolik, N. Jivane, M. Bhandari, and M. Venkatesan, "Twitter sentiment analysis of movie reviews using machine learning technique,” Int. J. Eng. Technol., vol. 7, no. 6, pp. 2038-2044, 2016.

[8] A. Surahman, "PENGEMBANGAN MARKET SEGMENTASI UNTUK MENCAPAI KEUNGGULAN BERSAING PADA E-MARKETPLACE,”J. Komput. dan Inform., vol. 15, no. 1, pp. 118-126, 2020.

[9] B. R. Feldman, "Techniques and Applications for Sentiment Analysis," Commun. Acm, vol. 58, no. 4, pp. 83-89, 2013.

[10] L. F. S. Coletta, N. F. F. da Silva, E. R. Hruschka, and E. R. H. Jr, "Combining classification and clustering for Tweet sentiment analysis Combining Classification and Clustering for Tweet Sentiment Analysis," in Brazilian Conference on Intelligent Systems, 2014, pp. 210-2015, doi: 10.1109/BRACIS.2014.46.

[11] I. D. I, I. Amirulloh, and D. Rosiyadi, “Analisis Sentimen Media Sosial Opini Ujian Nasional Berbasis Komputer menggunakan Metoda Naive Bayes,” J. Electr. Electron. Eng., vol. 1, no. 2, pp. 38-45, 2016.

[12] D. Alita, Y. Fernando, and H. Sulistiani, "Implementasi Algoritma Multiclass SVM pada Opini Publik Berbahasa Indonesia di Twitter,” J. Tekno Kompak, vol. 14, no. 2, pp. 86-91, 2020.

[13] J. Ling and T. B. Oka, "ANALISIS SENTIMEN MENGGUNAKAN METODE NAÏVE BAYES CLASSIFIER DENGAN SELEKSI FITUR CHI SQUARE,” E-Jurnal Mat., vol. 3, no. 3, pp. 92-99, 2014.

[14] A. Rahmawati, A. Marjuni, and J. Zeniarja, "Analisis Sentimen Publik Pada Media Sosial Twitter Terhadap Pelaksanaan Pilkada Serentak Menggunakan Algoritma Support Vector Machine," CCIT J., vol. 10, no. 2, pp. 197206, 2017.

[15] A. Surahman, A. F. O. P. Pasaribu, and D. Darwis, "Ekstraksi Data Produk e-Marketplace Sebagai Strategi Pengolahan Segmentasi Pasar Menggunakan Web Crawler," Sist. J. Sist. Inf., vol. 9, no. 1, pp. 73-81, 2020. 